\title{
ETIKA HINDU DALAM KEHIDUPAN
}

\author{
Anak Agung Gede Wiranata \\ Institut Agama Hindu Negeri Tampung Penyang Palangka Raya
}

\begin{abstract}
Abstrak
Pendidikan Formal mulai dari Sekolah Dasar sampai Perguruan Tinggi selalu mendapatkan pelajaran Agama. Pendidikan yang berbasis Agama atau Spiritual seperti Pesraman, Pesantren dan lain-lain selalu mendapatkan pelajaran Agama, begitu pula Pasraman-pasraman para sulinggih di masyarakat yang selalu mengajarkan kepada masyarakat umum, baik dari kalangan anak-anak, remaja maupun dewasa. Ajaran Filsafat Hindu menegarkan bahwa etika Hindu dalam kehidupan memberikan aturan dan norma untuk mengatur dalam melakukan tingkah laku yang baik dan mulia agar dapat menciptakan hubungan yang baik, harmonis baik itu di keluarga maupun di masyarakat.
\end{abstract}

Kata kunci: Etika Hindu, Pendidikan dalam kehidupan

\section{PENDAHULUAN}

Pendidikan Formal mulai dari Sekolah Dasar sampai Perguruan Tinggi selalu mendapatkan pelajaran Agama. Dengan adanya ajaran Agama seperti Catur Marga atau empat jalan menuju kesempurnaan hidup, Tri Kaya Parisudha atau tiga prilaku yang baik, Panca Yama Bratha atau lima macam pengendalian diri, Dasa Yama Bratha atau sepuluh cara Pengendalian diri, Dasa Dharma atau sepuluh perbuatan yang baik, Catur Paramitha atau empat perbuatan yang luhur menuju kesempurnaan hidup, semestinya sudah cukup untuk dijadikan pedoman hidup agar tercapainya Jagadhitayaitu kesejahteraan hidup di dunia ini, tapi kenyataannya masih banyak perbuatan yang melanggar norma-norma yang berlaku.
Pendidikan yang berbasis Agama atau Spiritual seperti Pesraman, Pesantren dan lain-lain selalu mendapatkan pelajaran Agama, begitu pula Pasraman-pasraman para sulinggih di masyarakat yang selalu mengajarkan kepada masyarakat umum, baik dari kalangan anak-anak, remaja maupun dewasa.

Agama Hindu mengajarkan tiga kerangka dasar antara lain Filsafat yang mengajarkan kebenaran Hakikat hidup, upacara yang mengajarkan simbulsimbul alam semesta beserta isinya untuk diketahui sebagai pegangan hidup, dan etika atau susila yang mengajarkan norma-norma atau aturan bertingkah laku, baik terhadap Tuhan, sesama, maupun lingkungan.

Penyimpangan-penyimpangan terjadi di kalangan anak-anak, remaja, 
dewasa. Dalam menempuh pendidikan Formal maupun Pendidikan non formal dari tingkat desa baik TK, SD, SMP, SMA, Perguruan tinggi, Pesantian, Perkumpulan Karang-Taruna, Sanggarsanggar, perkumpulan-perkumpulan spiritual, yang di aplikasikan dalam kegiatan sehari-hari seperti Dharma gita (lagu-lagu spiritual), tari-tarian, ceritacerita rakyat.

Pemerintah selalu memberikan pelayanan terhadap masyarakat seperti penyuluhan Agama, pendidikan moral, seminar-seminar, dialog terbuka, Dharma Wacana, dan menyediakan buku-buku Agama diperpustakaan serta mengimpormasikan dampak-dampak pelanggaran yang dilakukan masyarakat seperti tauran dikalangan pelajar, pemerkosaan, perampokan, sex bebas, pemakai narkoba, sampai sekarang masih banyak yang menyimpang.

Pendidikan formal sekarang ini membutuhkan biaya yang sangat tinggi akan menghasilkan Sumber Daya Manusia yang handal belum tentu menjamin manusia itu akan berbuat baik. Konsep Tri Hita Karana sangat penting untuk dipakai acuan. Hubungan antara Manusia dengan Tuhan, Manusia dengan Manusia, Manusia dengan Lingkungan. Dengan konsep tersebut Pendidikan nasional tidak akan berarti apa-apa kalau hanya dapat melahirkan orang-orang yang pintar tetapi rakus dan tamak tidak menyeimbangkan dirinya dengan lingkungan luar. Oleh karena itu, pendidikan harus diarahkan untuk membangun kesadaran kritis anak didik tentang berbagai hal, termasuk nilai-nilai moral, hak asasi manusia, kebenaran, keadilan, dan kejujuran. Dengan demikian, anak didik akan menyadari prilaku yang menyimpang itu tidak baik.

Selama ini, kalau diamati secara cermat, pendidikan di Indonesia hanya memberikan sebuah pengertian kepada peserta didik, tanpa pernah bisa memfasilitasi pembentukan watak. Pendidikan terlalu didominasi oleh lingkaran kognitif, konsep-konsep, norma-norma, dan nilai agama serta adat istiadat banyak dibaca dan dihafalkan begitu saja, tetapi sedikit sekali terefleksi untuk merenungi apa sesungguhnya yang telah dibaca dan dipelajari tersebut, sehingga implementasinya dalam kehidupan sangat jauh. Mata pelajaran atau pendidikan agama dan pendidikan kewarganegaraan yang menjadi pelajaran wajib selama ini dari tingkat sekolah dasar sampai Perguruan tinggi, yang mengajarkan keutamaan, kebaikan, kehalusan budi, solidaritas, dan toleransi kepada sesama manusia sepertinya tidak berbekas.

Kehidupan sehari-hari apabila implementasi sistem pendidikan tetap 
dibiarkan seperti itu, maka para peserta didik yang kelak menjadi pemimpin dan pewaris bangsa ini hanya mampu membuat pidato-pidato atau rencanarencana yang hanya enak didengar tanpa mampu mengimplementasikannya. Nilai moral hanya sebatas imperatif yang tidak menyentuh pergulatan kehidupan manusia sehari-hari. Sehingga tidak akan mampu memadukan akal dan perasaan untuk menimbang baik dan buruk suatu perbuatan atau keputusan yang akan diambil dan cenderung akan banyak bergantung pada pendapat orang lain tanpa mampu menyaringnya terlebih dahulu, sehingga tidak akan mampu hidup mandiri.

Tampak jelas bahwa agenda pendidikan ke depan harus mulai mengutamakan pendidikan yang mampu menciptakan manusia beretika, yaitu manusia yang mampu menggunakan akal dan perasaan untuk menimbang baik dan buruknya sesuatu dengan berlandaskan nilai-nilai luhur, normanorma agama, dan adat-istiadat dalam perikehidupan.

\section{PEMBAHASAN}

a. Pengertian Etika

Kata etika berasal dari kata ethos (bahasa Yunani) yang mempunyai banyak arti : watak, perasaan, sikap, perilaku, karakter, tatakrama, tatasusila, sopan-santun, cara berpikir
(Suhardana,2006:1).Etimologi kata "etika" sama dengan etimologi kata "moral", karena keduanya berasal dari kata yang berarti adat kebiasaan. Hanya bahasa asalnya berbeda. Yang pertama berasal dari bahasa Yunani, sedang yang kedua dari bahasa latin (K, Bertens, 1994:5).

Etika dalam agama Hindu dinamakan "susila". Kata "susila" berasal dari dua suku kata yakni "su" dan "sila". Su artinya baik, sila berarti kebiasaan atau tingkah laku perbuatan manusia yang baik. Karena itu dalam agama Hindu, etika dikatakan sebagai ilmu yang mempelajari tata nilai, tentang baik dan buruknya suatu perbuatan apa yang harus dikerjakan atau dihindari, sehingga tercipta hubungan yang baik diantara sesama manusia. Salah satu aspek dalam ilmu etika adalah membahas aspek moral dan arti dari apa yang dikatakan baik dan tidak baik. Etika adalah rasa cinta, rasa kasih sayang dimana seseorang yang menerima etika itu adalah karena ia mencintai dirinya sendiri dan menghargai orang lain (Pudja, 1984 dalam Suhardana, 2006:19)

Dalam Agama Hindu Etika dinamakan tata susila yang artinya sebagai peraturan tingkah laku baik dan mulia yang harus dijadikan pedoman hidup oleh manusia. Tujuannya adalah untuk memelihara hubungan baik yang selaras dan serasi diantara sesama 
manusia, sehingga tercapailah

kehidupan masyarakat yang aman dan sentosa. Tata susila membina watak manusia untuk bisa menjadi anggota keluarga dan anggota masyarakat yang baik, menjadi putra Bangsa yang berpribadi mulia. Landasan atau pedoman dasar etika Hindu adalah Kitab Suci Weda.

Sejalan dengan pendapat di atas, (Suhardana, 2006:21) etika Hindu bertujuan untuk: 1) membina agara umat Hindu dapat memelihara hubungan baik, hidup rukun dan harmonis dengan keluarganya ataupun dengan orang lain. 2) untuk menghindarkan adanya hukum rimba, dimana yang kuat menindas yang lemah. 3) untuk membina agar umat Hindu dapat menjadi manusia yang baik dan berbudi luhur. 4) untuk membina agar umat manusia selalu bersikap dan bertingkahlaku baik terhadap siapapun juga.

\section{b. Etika Dalam Sastra Hindu}

Dalam ajaran Agama Hindu sangat banyak mantra-mantra atau sloka-sloka yang menyangkut tentang pendidikan etika diantaranya : Kitab Bhagawadghita,

Manawa

Dharmasastra,

Silakrama,

Sarassamuscaya, Slokantara, Nitisastra, Sucita.

\section{Bhagawadgita}

"Wahai Penakluk musuh, korban suci yang dilakukan dengan Pengetahuan lebih baik dari pada hanya mengorbankan harta benda material. Wahai Putra Partha (Arjuna), bagaimanapun, maka segala korban suci yang terdiri dari pekerjaan memuncak dalam pengetahuan rohani" (Bhagawadghita, Sloka 4.33). Sloka Bhagawadghita ini artinya kalau di hubungkan terhadap pelajar atau Siswa, bahwa seorang pelajar paling berpotensi untuk memenuhi isi dari Bhagawadghita tersebut karena yang paling banyak punya waktu untuk belajar adalah pelajar dan kemudian kalau di gunakan untuk kepentingan umat manusia merupakan persembahan yang paling tinggi dari pada persembahan yang lainnya kepada Tuhan. Karena merupakan persembahan yang paling tinggi, kepada para Siswa atau pelajar hendaknya mendapatkan pengetahuan dengan sebanyak-banyaknya kemudian di gunakan untuk kepentingan umat manusia di dunia ini.

Sloka Bhagawadghita di atas berarti segala korban suci dimaksudkan untuk mencapai status pengetahuan yang lengkap, kemudian memperoleh pembebasan dari 
kesengsaraan material, dan akhirnya menekuni cinta-bhakti rohani kepada Tuhan Yang Maha Esa. Walaupun demikian, ada rahasia mengenai segala kegiatan korban suci tersebut, dan hendaknya orang mengetahui tentang rahasia ini. Kadang-kadang ada berbagai bentuk korban suci menurut kepercayaan tertentu yang dianut oleh pelaksana korban suci itu. Apabila kepercayaan seseorang mencapai pada tahap pencapaian rohani, harus dianggap orang yang melaksanakan korban-korban suci itu lebih maju dari pada orang yang hanya mengorbankan harta benda material tanpa pengetahuan seperti itu; sebab tanpa mencapai pengetahuan, korbankorban tetap pada tingkat material dan tingkat menganugrahkan berkat rohani.

Sloka di atas secara luas berarti jalan untuk mencapai ke insafan tentu sulit. Karena itu, Tuhan menasehati agar mendekati seorang Guru kerohanian, yang dapat di percaya dalam garis Perguruan dari Tuhan sendiri. Didak seorangpun dapat menjadi seorang Guru kerohanian yang dapat di percaya tanpa menuruti prinsip garis Perguruan rohani tersebut. Kresna (Tuhan) adalah Guru kerohanian yang asli, dan orang yang termasuk garis Perguruan dapat menyampaikan amanat Kresna menurut aslinya kepada muridnya. Tidak ada orang yang insaf secara rohani dengan membuat proses sendiri, seperti yang telah menjadi mode di kalangan orang bodoh yang berpura-pura.

Seorang juga tidak dapat maju dalam kehidupan rohani dengan cara mempelajari buku-buku pengetahuan sendirian. Orang harus mendekati seorang Guru kerohanian yang dapat di percaya untuk menerima pengetahuan. Seorang Guru kerohanian seperti itu harus di terima dengan penyerahan diri sepenuhnya, dan sebaiknya orang mengabdikan diri kepada sang Guru kerohanian seperti harus hamba yang rendah, bebas dari kemasyuran yang palsu.

Memuaskan sang Guru yang sudah insaf akan dirinya rahasia kemajuan dalam kehidupan rohani. Sikap rendah hati, dan pengabdian diri kepada Guru kerohanian, apa yang di ajarkan oleh seorang Guru akan cepat mengerti. Seseorang sanggup lulus ujian sang Guru kerohanian dan apa bila Guru kerohanian melihat keinginan yang tulus di dalam hati sang murid, dengan sendirinya beliau menganugrahi murid itu dengan pengertian rohani yang sejati 
(Prabhupada, 2000:261).

"Walaupun engkau dianggap sebagai orang yang paling berdosa diantara semua orang yang berdosa, namun apabila engkau berada di dalam kapal pengetahuan rohani, engkau akan dapat menyeberangi lautan kesengsaraan" (Bhagawadghita sloka 4.36). Sloka ini kalau di hubungkan dengan Siswa dalam menempuh pengetahuan adalah pengetahuan rohani (bijaksana) dapat menyelamatkan diri dari lautan yang paling berdosa sekalipun. Maka dari itu setelah pengetahuan di dapatkan, gunakan dengan sebaik-baiknya agar berguna bagi masyarakat yang memerlukan dan bagi kehidupan di dunia ini. Terkait dengan sloka tersebut terdapat juga dalam (Bhagawadghita sloka 4.37) "seperti halnya api yang berkobar mengubah kayu bakar menjadi abu, begitu pula api pengetahuan membakar segala reaksi dari kegiatan material hingga menjadi abu, wahai arjuna". Sloka ini kalau di kaitkan dengan Siswa dalam menempuh pengetahuan, adalah kegelapan atau kebodohan akan lenyap oleh apinya pengetahuan.

Pengetahuan sempurna tentang sang diri dan diri yang utama serta hubungannya di umpamakan sebagai api dalam ayat ini. Api tersebut tidak hanya membakar reaksi dari kegiatan yang tidak saleh, tetapi juga reaksi kegiatan yang saleh, dan mengubah segala reaksi itu menjadi abu.

Dunia ini, tiada sesuatupun yang mulia dan sesuci pengetahuan yang melampaui hal-hal duniawi. Pengetahuan seperti itu adalah buah matang dari segala kebatinan. Orang yang sudah ahli dalam latihan bhakti menikmati pengetahuan ini dalam dirinya sesudah beberapa waktu" (Bhagawadghita sloka 4.38).

Membicarakan pengetahuan yang melampui hal-hal duniawi, membicarakan hal itu menurut pengertian rohani. Karena itu tidak ada sesuatupun yang mulia dan sesuci pengetahuan yang melampui hal-hal duniawi. Kebodohan menyebabkan keterikatan dan pengetahuan membebaskan, pembebasan adalah buah matang dari bhakti, apabila orang sudah mantap dalam pengetahuan yang melampaui hal-hal duniawi maka ia tidak perlu mencari kedamaian di tempat lain, pengetahuan dan kedamaian ini memuncak dalam kesadaran Tuhan.

“Orang setia yang sudah menyerahkan diri pada pengetahuan 
yang melampaui hal-hal duniawi dan menakklukan indria-indrianya memenuhi syarat untuk mencapai pengetahuan seperti itu, dan setelah mencapai pengetahuan itu, dengan cepat sekali ia mencapai ke damaian rohani yang paling utama" (Bhagawadghita sloka 4.39).

Pengetahuan tersebut dalam kesadaran Tuhan dapat di capai oleh orang yang setia yang percaya dengan teguh kepada Tuhan. Seseorang di sebut setia kalau ia berpikir bahwa hanya dengan bertindak dalam kesadaran Tuhan ia dapat mencapai kesadaran tertinggi. Keyakinan tersebut dapat di capai dengan pelaksanaan bhakti, serta harus mengendalikan indria-indrianya. Orang yang setia kepada Tuhan dan mengendalikan indria-indrianya dengan mudah dapat mencapai kesempurnaan dalam pengetahuan kesadaran Tuhan (Prabhupada, 2000:266).

\section{Manawa Dharma Sastra}

“Ucapkanlah pranawa Om pada awal dan akhir pelajaran, kalau tidak diawali Om, pelajaran bisa menyasar, kalau tidak ditutup dengan Om, pelajaran akan menghilang" (Manawa Dharma Sastra. Buku II. sloka 74). sloka ini berarti sebelum dan sesudah belajar, Siswa hendaknya mengingat
Tuhan dengan berdoa baik saat mulai belajar maupun pada akhir pelajaran, karena Tuhan yang merupakan sumber dari segala pengetahuan.

"Dengan mengendalikan perbuatan, perkataan, panca indria dan pikiran maka ia itu hendaknya berdiri dengan mencakupkan tangan serta memandang muka Gurunya" (Manawa Dharma Sastra. Buku II sloka 192). bahwa seorang Siswa itu hendaknya selalu sadar untuk mengendalikan pikiran, perkataan dan perbuatannya Memberikan pengormatan kepada Guru yang akan memasuki ruangan belajar. "Di hadapan Gurunya, ia hendaknya makan lebih sedikit, berpakaian lebih sederhana dan ia harus bangun lebih pagi dan tidur lebih malam dari Gurunya" (Manawa Dharma Sastra. Buku II sloka 194).

"seorang Siswa tidak boleh menjawab atau bercakap-cakap dengan Gurunya sambil berbaring, ataupun duduk di atas pembaringan, sambil makan, sambil berdiri, atau bangkit dengan muka yang tidak ditujukan pada muka Gurunya" (Manawa Dharma Sastra. Buku II sloka 195). Seorang Siswa harus terlatih dengan siapa dia berbicara, sopan-santun kalau diajak berbicara dan menghormat bila ketemu dengan 
Guru.

"Ia tidak boleh menyebut nama Gurunya begitu saja tanpa di beri tambahan kata penghormatan walaupun tidak di hadapan Gurunya dan ia tidak boleh meniru-niru cara berjalan, cara berbicara dan gerakgerik Gurunya" (Manawa Dharma Sastra.II.199). "Dengan mengkritik Gurunya, ia akan menjelma menjadi keledai, sedangkan kalau seseorang Siswa menjelek-jelekkan Gurunya secara fitnah ia akan menjelma menjadi anjing, ia yang hidup dari keringat Gurunya ia akan lahir menjadi cacing, jika seorang Siswa menaruh irihati terhadap keberuntungan Gurunya ia akan menjadi serangga dalam kelahirannya yang akan datang" (Manawa Dharma Sastra.II.201).

Sloka di atas menerangkan hukum karma phala dari akibat perbuatan Siswa yang mengkritik, mengina dan memfitnah Gurunya. Ancaman lahir sebagai binatang adalah bentuk hukuman yang tidak dikehendaki oleh setiap orang. Secara spiritual setiap orang ingin memperoleh kelahiran yang lebih baik pada kelahiran yang akan datang dan kalau perlu tidak lahir ke dunia samsara ini. Untuk memperoleh pemberkatan seorang maka seorang
Siswa harus selalu menghormati para Guru (Donder, 2004:136).

"Ia tidak boleh melayani Gurunya karena disuruh oleh orang lain sedangkan dia sendiri hendak berpangku tangan atau pada waktu ia marah, ataupun kalau ada perempuan di dekatnya, kalau ia sedang duduk di dalam kendaraan atau tempat duduk yang lebih tinggi dia harus turun dan kemudian memberi hormat kepada Gurunya" (Manawa Dharma Sastra. Buku II sloka 202).

Manawa Dharma Sastra.II sloka 202 berarti melayani seorang Guru harus dengan tulus ikhlas yang datangnya dari lubuk hati paling dalam tidak atas suruhan orang lain. Dimana pun ketemu dengan Gurunya harus selalu memberi hormat kepada Gurunya serta membantu Gurunya.

"Demikian juga hendaknya, tingkah lakunya kepada Guru-Guru bidang ilmu pengetahuan lainnya. Juga yang patut dihormati adalah semua orang yang memberikan nasihat untuk kebaikan" (Manawa Dharma Sastra. Buku II sloka 206). Sloka ini artinya barang siapa yang pernah memberi nasehat untuk kebaikan, maka harus di hormati. Jangan pernah lupa untuk mengingat kebaikan orang lain, walaupun hanya sedikit. 
"Kepada orang yang lebih tinggi (terhormat, sesepuh) daripadanya maka hendaknya berbuat sebagaimana terhadap Gurunya, demikian juga terhadap putra-putri Gurunya, terhadap keluarga-keluarga Gurunya baik dari garis bapak maupun garis ibu" (Manawa Dharma Sastra. Buku II sloka 207) sloka ini berarti walaupun bukan Gurunya apalagi orang tersebut lebih tua, lebih senior, walaupun orang itu tidak dikenal, demikian pula terhadap keluarga Guru tetap harus hormat.

"Putra dari seorang Guru yang memberikan pelajaran menggantikan Gurunya walaupun lebih muda atau sebaya, tentang pelajaran upacara atau bagian Weda lainnya berhak mendapat penghormatan sebagaimana layaknya seorang Guru " (Manawa Dharma Sastra.Buku II sloka 208).

"Seorang yang telah berumur 20 tahun dan sudah tahu mana yang baik dan mana yang buruk, tidak boleh menghormati istri Gurunya yang usianya masih muda dengan cara memegang kakinya"

(Manawa Dharma

Sastra.Buku II sloka 212). Sloka ini berarti untuk menghindari terjadi halhal yang tidak diinginkan oleh Siswa itu sendiri karena istri Gurunya itu lebih muda dari Siswa itu sendiri, yang bertujuan untuk menghindari jatuh cinta antara istri Guru dengan Siswa kalau itu terjadi sama dengan mencintai Gurunya sendiri.

"Kalau Matahari terbit atau terbenam sementara ia tidur secara disengaja atau tidak, ia harus berpuasa pada hari berikutnya dengan menguncarkan mantram Sawitri”, (Manawa Dharma Sastra.Buku II sloka 220). Sloka ini untuk menghindari terjadinya kemalasan bagi Siswa, karena kalau tidur sudah siang badan menjadi kurang sehat, begitu juga kalau tidur terlalu sore sampai Matahari terbenam, karena baik pagi maupun sore hari waktuwaktu yang baik untk bermeditasi atau semabhyang.

"Guru, ayah, ibu dan kakak tidak boleh diperlakukan dengan tidak hormat, teristimewa bagi para rohaniawan yang mulia, walaupun seorang Siswa itu merasa telah pernah disakiti hatinya oleh mereka" (Manawa Dharma Sastra.Buku II sloka 225). Menjadi Siswa tidak boleh dendam terhadap Guru, terhadap ayah, terhadap kakak karena semua itu merupakan orang yang berjasa. Seorang Guru menyebabkan pintar, orang tua yang menyebabkan ada, kakak menyebabkan kebahagian, maka dari itu seorang Siswa tidak boleh memperlakukan tidak hormat 
Sejalan dengan sloka di atas di jelaskan kewajiban Siswa dalam Manawa Dharma Sastra.Buku II sloka 226 adalah "Guru adalah gambaran dari Tuhan Ayah adalah gambaran dari Prajapati, Ibu adalah gambaran dari Prthiwi dan kakak adalah gambaran dari diri sendiri" (Manawa Dharma Sastra.Buku II sloka 226). oleh sebab itu, seorang Siswa harus menghormati semuanya Sloka ini memberikan gambaran agar Siswa tidak ragu-ragu untuk menghormati yang patut di hormati.

"Seorang anak harus selalu melakukan apa yang di setujui ke dua orang tuanya dan apa yang menyenangkan Gurunya. Kalau ketiga orang tua itu (ibu, ayah dan Guru) senang maka ia mendapatkan segala pahala dari tapabratanya" (Manawa Dharma Sastra.Buku II sloka 228). Sloka ini berarti apapun yang dilakukan pasti ada buahnya, banyak yang di perbuat banyak mendapatkan hasil, sedikit berbuat sedikit hasil yang di peroleh. Logikanya kalau ketiga orang tersebut di hormati maka diri sendiri pasti di sayangi, karena di sayangi itu merupakan pahala bagi diri sendiri

"Ia yang tidak mengabaikan ketiga api itu (simbol; ayah, ibu dan Guru) walaupun ia itu sudah menjadi kepala keluarga, ia yang seperti itu akan dapat menaklukkan ketiga dunia dan ia yang demikian badannya akan bercahaya sebagai dewa dan akan menikmati kebahagiaan di surga" (Manawa Dharma Sastra.Buku II sloka 232). "Dengan menghormati ibunya ia akan mencapai kebahagiaan di atas dunia ini. Dengan menghormati ayahnya ia akan menikmati dunia tengah atau manusia ini dengan bahagia. Tetapi dengan ketaatan terhadap Gurunya ia akan mencapai alam Brahman" (Manawa Dharma Sastra.Buku II sloka 233)

"Hendaknya ia mengatakan apa yang benar, hendaknya ia mengucapkan apa yang menyenangkan hati, hendaknya ia jangan mengucapkan kebenaran yang tidak menyenangkan, dan jangan pula ia mengucapkan kebohongan yang menyenangkan, ini hukum hidup duniawi yang abadi" (Manawa Dharma Sastra, IV. 138). Sloka ini berarti seorang Siswa tidak boleh berkata yang bisa melukai hati orang lain. Berkata yang jujur, enek di dengar, lemah lembut.

“Oleh karena itu hendaknya setiap orang harus sedikit demi sedikit mengumpulkan kebajikan-kebajikan spiritual untuk nantinya dijadikan kawan setelah meninggal, karena hanya dengan 
kebajikan-kebajikan spiritual itulah akan mampu menembus kegelapan yang sukar ditembus dalam perjalanan ke dunia berikutnya" (Manawa Dharma Sastra, IV. 242). "Kebajikan sebagai kawannya itu, maka kebajikan itu akan dengan cepat mengajak jiwa itu ke dunia berikutnya, manusia yang taat pada kewajiban hidup serta selalu membersihkan dosa-dosanya dengan tapa brata, sehingga ia menjadi bercahaya dan berselubung dengan badan yang halus dan gaib" (Manawa Dharma Sastra.Buku IV. 243).

"Disuruh atau tidak oleh Gurunya seorang Siswa harus selalu menurut kan diri terhadap kewajiban untuk mempelajari Weda (semua ilmu pengetahuan) dan melakukan pelayanan kepada Gurunya" (Manawa Dharmasastra, II.191). Sloka ini berarti dapat ditekankan dalam pembelajaran adalah seorang Siswa harus selalu memperhatikan hak dan kewajibannya dan selalu serius dan memperhatikan Gurunya dalam pembelajaran. Walaupun Siswa sudah tamat dari belajarnya, Siswa harus tetap rajin belajar dan tidak boleh melupakan Gurunya karena berkat Gurunyalah mereka bisa sukses dan berhasil.

"Ka1au Gurunya, tempatnya berdekatan hendaknya tempat tidur atau tempat duduk simurid supaya lebih rendah dan ia tidak boleh duduk dengan cara sembarangan jika dilihat Gurunya" (Manawa Dharmasastra :II.198). sloka ini berarti kalau Siswa ketemu dengan Guru dimana saja tidak boleh duduk atau berdiri lebih tinggi dari Gurunya, Siswa harus selalu memberi hormat.

Sloka ini dapat juga memberikan pedoman agar seorang Siswa selalu menempatkan dirinya baik secara fisik maupun mental berada di bawah kedudukan Gurunya. Seorang Siswa tidak boleh menganggap dirinya sama dengan Gurunya. Jika hubungan Guru dan Siswa diibaratkan sebagai hubungan dua bejana atau alat penampung, maka Guru sebagai bejana pemberi harus ditempatkan pada kedudukan yang lebih tinggi. Hal ini sekaligus memberikan pengertian bahwa Siswa sebagai bejana penerima, mau atau tidak mau harus ditempatkan pada posisi di bawah bejana Guru. Hal ini dilaksanakan agar air pengetahuan dari bejana Guru mengalir ke bejana Siswa (Donder, 2004:133)

Berdasarkan pandangan modern, dalam teori belajar tidak boleh lagi menganggap Siswa sebagai bejana, namun dalam konteks bahasa maupun dalam konteks konkrit tidak dapat dihindari adanya anggapan bahwa Siswa itu dianggap bejana. Dengan adanya istilah, bahwa tugas dan kewajiban seorang Siswa itu adalah "menimba" 
berbagai ilmu pengetahuan, maka mau tidak mau, senang atau tidak senang, maka Siswa itu secara inplisit telah dipandang sebagai bejana. Hanya saja istilah bejana pada masa 1alu terkesan hanya sebagai objek yang diisi oleh Gurunya, sedangkan kesan pada pengertian kedua yaitu "menimba" ada1ah sebagai pelaku atau subjek yang secara aktif mencari sesuatu yang diisikan atau dimasukkan dalam bejana (Donder, 2004:133).

Posisi bejana yang digunakan untuk menimba harus berada di bawah permukaan level zat cair yang ditimbanya. Bila bejana yang digunakan untuk menimba tidak dimasukkan hingga di bawah level permukaan zat air itu, maka niscaya bejana itu tidak pernah berisi zat cair yang ditimbanya. Ini merupakan hukum alam sekaligus hukum spiritual yang kebenarannya universal dan tidak dapat dibantah lagi (Donder, 2004:133-1334).

"Guru adalah gambaran dari Brahman (Tuhan), Ayah adalah gambaran dari Prajapati, Ibu adalah gambaran dari Prtwi, Kakak adalah gambaran dari diri sendiri" oleh sebab itu jangan ragu-ragu menghormati semuanya (Manawa Dharmasastra, II:226). Dapat ditegaskan kembali setelah menuntut ilmu yang tinggi seorang Siswa agar tetap hormat dan beretika terhadap orang yang lebih tua serta harus bisa membalas budi baiknya.

"Hendaknya ia berjalan, di dunia fana ini, menyesuaikan pakaiannya, Ia harus dapat menyesuaikan pikiran, perkataan dan perbuatan sebagaimana ketentuan umum, kedudukan, pelajaran sucinya, dan juga kebangsaannya. kekayaan agar ia hidup sesuai dengan pengetahuan suci yang telah diterimanya" (Manawa Dharma Sastra, IV.18).

Dapat ditegaskan kembali yaitu seorang Siswa harus mempunyai wawasan yang luas, mengetahui/ menguasai ajaran dalam berbagai lini kehidupan, karena semakin dalam seseorang Siswa mempelajari ilmu pengetahuan, maka lebih dalam pulalah ia mengerti semuanya dan kepandaiannya akan bercahaya terang pada wajahnya

"Oleh karena itu hendaknya setiap ia harus sedikit demi sedikit mengumpulkan kebajikan-kebajikan spiritual untuk nantinya dijadikan kawan setelah meninggal, karena hanya dengan kebajikan-kebajikan spiritual itulah akan mampu menembus kegelapan yang sukar ditembus dalam perjalanan ke dunia berikutnya"

(Manawa Dharmasastra, IV:242). Ini berarti 
seorang Siswa dituntut untuk mewujudkan karakter/ kebijaksanaan, karena kalau setelah meninggal nanti akan menjadi bekal di alam berikutnya, sedangkan bagi manusia yang mengutamakan kebutuhan duniawi daripada kebutuhan sepiritual akan lahir kembali ke dunia ini sesuai dengan kualitas perbuatannya.

\section{Sarasamuscaya}

"Manfaatkanlah kesempatan menjadi manusia, karena sangat sulit untuk diperoleh laksana meniti tangga menuju sorga, pegang teguh semua penyebab kejatuhan" (Sarassamuscaya, sloka 6). Sloka ini bagi pelajar artinya jangan menyianyiakan waktu semasih masih muda, gunakanlah waktu dengan baik sewaktu masih pelajar karena akan menentukan kualitas hidup untuk selanjutnya. Jangan bermalasmalasan.

"Yang harus anda perhatikan Perbuatan, kata-kata dan pikiran yang tidak menyenangkan dirimu sendiri bahkan menimbulkan duka kesusahan dan sakit hati yang seperti itu jangan dilakukan kepada orang lain, itulah dharma namanya, jangan dilakukan menyimpang (Sarassamuscaya, sloka 41).

"Yang patut dilakukan adalah berikut ini: jangan menjawab secara berolok-olok kepada Gurunya. Jika Guru dalam keadaan gusar, berang hatinya, buatlah suasana di sekelilingnya menjadi tenang, sabarkan beliau, hiburlah usahakan agar segala yang menyenangkan hatinya dapat dikondisikan (Sarassamuscaya:237)

"Lagi pula, janganlah sekali-kali mencela Guru, meskipun keliru perbuatan beliau, hendaklah diusahakan baik-baik cara perlakuan yang layak untuk mengingatkan kekeliruannya, agar berhasil melaksanakan bhakti dan pengabdian kepada Guru. Sangatlah menyebabkan usia pendek serta menimbulkan dosa jika menghina Guru" (Sarassamuscaya:238)

Ayah, ibu dan Guru adalah tiga serangkai yang tidak terpisahkan dalam usaha mewujudkan anak yang berkarakter. Oleh sebab itu ketiganya patut dihormati. Bagaimana seharusnya seorang anak menghormati orangtuanya, di bawah ini kitab Sarasamussaya menguraikannya: "Orang yang senantiasa setiap hari hormat kepada ibu dan ayahnya disebut tetap teguh melakukan tapa dan selalu menyucikan dirinya dan tetap teguh berpegang kepada kebenaran dan dharma" (Sarassamuscaya:239)

Lebih lanjut diuraikan dalam Sarassamuscaya mengatakan: "Setia 
dan bhakti terhadap orangtuanya, membuat orangtuanya sangat senang dan puas hatinya, pahalanya tetap akan diterima baik saat berbuat maupun di masa mendatang dan akan mendapat pujian karena telah melaksanakan kebajikan" (Sarassamuscaya:241)

"Oleh karena itu prilaku terhadap orangtua, hendaknya selalu memberi salam selamat dan menyapanya dengan sopan santun, mempersilahkan duduk, bersila serta dengan sikap sopan duduk di dekatnya atau di hadapannya, ketika beliau hendak berangkat hendaklah dihantarkan" (Sarassamuscaya:248).

\section{Slokantara}

"Seorang yang tidak mau mengakui Gurunya, ia yang tidak mau mengakui orang yang telah memberikan pelajaran kepadanya walaupun hanya satu huruf saja, maka Siswa yang melupakan seperti itu setelah kematiannya akan lahir mula-mula sebagai anjing dan setelah itu akan menjadi manusia hina dina" (Slokantara:28)

\section{Silakrama}

Kitab

Suci

Silakrama menyebutkan tentang etika Siswa "Inilah tata tertib dalam berGuru (menuntut ilmu), janganlah tidak bhakti terhadap Guru, Janganlah mencaci maki Guru, Jangan segan kepada Guru, jangan tidak tulus kepada Guru, jangan menentang segala perintah Guru,jangan menginjak bayangan Guru, jangan menduduki tempat duduk Guru" Oka Puniatmaja (1970:23) (dalam Donder.2004:126).

Sloka ini berarti Seorang Siswa tidak boleh melawan Guru, berbohong kepada Guru, tidak boleh membicarakan Guru, harus selalu melakukan perintah Guru dan selalu hormat kepada Guru dan berarti seorang Siswa tidak boleh bersikap kurang baik terhadap Gurunya. Seorang Siswa harus ikhlas terhadap Gurunya, tidak boleh menentang, tidak boleh menduduki tempat sucinya.

Berkaitan dengan disiplin Siswa bhakti terhadap Guru ini Oka Puniatmadja (1970:24) (dalam Donder.2004:127) menguraikan bahwa: tata tertib, sujud bhakti dan sikap hormat para Siswa kerohanian terhadap Guru yang mendidik pribadi dan mencurahkan ilmu pengetahuan sucinya terhadap para Siswa itu. ketentuan-ketentuan yang diperuntukkan bagi Siswa agar mereka tumbuh menjadi orang-orang yang memiliki disiplin mental yang tangguh. Oka Puniatmadja menulis ketentuanketentuan tersebut sebagai berikut : 
a. Seorang Siswa tidak boleh duduk berhadap-hadapan dengan Gurunya.

b. Seorang Siswa tidak boleh memutus-mutus pembicaraan Gurunya.

c. Seorang Siswa harus menurut dengan apa yang diucapkan oleh Gurunya.

d. Apabila Gurunya datang seorang Siswa harus turun dari tempat duduknya.

e. Bila melihat Gurunya berdiri atau berjalan seorang Siswa harus mengikuti di belakangnya.

f. Bila bertanya kepada Guru seorang Siswa tidak boleh sambil menolah-noleh ke sana-kemari agar perhatian tidak pudar.

g. Seorang Siswa harus selalu menyahut dengan ucapan yang menyenangkan hati (manohara).

h. Walaupun bagaimana marahnya Siswa namun bila Gurunya menasehati maka seorang Siswa harus menurut

\section{Kearifan Lokal Bali tentang Etika}

\section{1) Matilesang Raga}

Metilesang raga dalam hal ini misalnya; punya hajatan. Saudara islam ditempatkan pada daging bukan babi, jadi harus disesuaikan, begitu juga kalau ada yang fegetarian. Untuk menjadi pemimpin kalau ada yang lebih mampu, kita dukung

\section{2) De Ngaden Awak Bisa}

Dalam hal ini artiya tidak diperbolehkan untuk mengaku-ngaku pintar, tapi kalau di tunjuk atau dipilih harus mau menerimanya

\section{3) Bani ngadep, bani meli}

Dalam hal ini iklas menjual artinya tidak rugi dan bagi yang membeli, iklas membeli dengan tidak merasa kemahalan. Jadi kalaupun barang yang akan dijual sendiri punya, kita jual tidak mengangkat harga terlalu mahal. Tetap kita jual asalkan yang membeli bisa membelinya dengan iklas tidak merasa kemahalan

\section{4) Nyama Selam}

Artinya walaupun orang dari luar bali, dan beda agama kita harus mengakui bahwa mereka saudara (nyama).

\section{5) Sing dadi negak di galeng}

Etika ini agar tidak mencampur adukan di mana tempat kepala, maupun tempat kaki, pantat atau di mana tempat untuk bagian atas, di mana tempat untuk bagian bawah, tidak di campur aduk

6) Mekecuh arep menek 
Dalam hal ini artinya tidak boleh menggosip, membicarakan saudara, teman, karena sebenarnya diri sendiri yang dibicarakan

7) Kuping ngeliwatin tanduk. Kita sebagai bawahan melewati atasan atau bos

8) Taluh apit batu. Serba sulit, kesana sulit, kesini juga sulit

9) Aduk Sera Aji keteng, artinya kebaikan masyarakat di sebuah desa di jelekkan oleh satu orang atau beberapa orang, akhirnya semua kena jeleknya

10) Nanduring tegal awak, artinyaselalu mengisi diri sendiri, tidak menyalahkan orang lain, bersyukur terhadap diri sendiri, cinta produk dalam negeri, memajukan desa sendiri

\section{1) Magantung bok akatih,} artinyahampir-hampir meninggal/mati, kearifan local ini sangat cocok diberikan kepada anak-anak agar mereka sadar betapa sulitnya dilahirkan oleh orang tua, agar nantinya anak tidak berani kepada orang tuanya.

12) Sagalak-sagilik salulung sabayantaka sarpanaya/Saling asah, asih, asuh.artinyasaling membantu, saling menghormati, toleransi untuk tetap mejaga persatuan

\section{KESIMPULAN}

Hindu memiliki dasar agama yang kuat untuk dijadikan acuan dalam menuntun umatnya melakukan perbuatan sesuai dengan jalan Dharma. Berbagai ajaran diberikan dalam kitabkitab suci yang ada di Agama Hindu untuk mengatur etika hidup umat Hindu. Etika Hindu tersebut dapat berupa dasar atau pedoman yang dijadikan panutan bagi siswa untuk menghormati Guru sebagai Guru Pengajian. Etika Hindu yang tertuang dari berbagai kitab suci juga dapat digunakan untuk membina umat Hindu agar terciptanya harmonisasi dan kerukunan baik dalam kehidupan keluargam maupun masyarakat.

Etika Hindu mengatur pedoman umat Hindu dalam melakukan perilaku dan tingkah laku sehingga akan menghasilkan Susila yaitu perilaku yang baik dimana nantinya menjadi pedoman dalam hidup manusia.

\section{DAFTAR PUSTAKA}

Awanita, dkk. 1993. Sila dan Etika Hindu. Jakarta : Direktorat Jendral Bimbingan Masyarakat Hindu dan Budha.
Donder.2008. Acarya Sista : Guru dan Dosen yang Bijaksana Perspektif Hindu. Paramita: Surabaaya

Franz. 1979. Etika Umum. Yogyakarta : Yayasan Kanisius 
K. Bertens. 1994. Etika. Jakarta:

Gramedia Pustaka Utama.

Kadjeng, dkk. 2003. Sarascamuscaya. Surabaya: Paramita

Oka, IG. 1994. Slokantara. Jakarta : Hanuman Sakti.

Prabhupada. 2000. Bhagavad-Gita Menurut Aslinya. Hanuman Sakti

Pudja, G. 2003. Manawa Dharmasastra (Manu Dharmasastra). Jakarta : Mitra Jaya

Puniatmadja, Oka. 1976. Sila Krama. Jakarta : Parisadha Hindu Dharma Pusat

Puniatmadja, Oka. 1994. Dharma Sastra. Jakarta : Hanuman Sakti

Suhardana. 2006. Etika dan Moralitas Hindu Bahan Kajian Untuk Memperbaiki Tingkah laku. Surabaya : Paramita.

Sardiman. 2006. Interaksi dan Motivasi Belajar Mengajar. Jakarta : Pt Raja Grafindo Persada. 